\title{
Policing in Print: Social Control in Spanish and Borromean Milan (1535-1584)
}

\author{
Rachel Midura
}

In 1580, the archbishop of Milan, Cardinal Carlo Borromeo, and Spanish governor, Antonio de Guzmán y Zuñiga, Marquis de Ayamonte, appeared to be at an implacable standoff. Six years prior, Borromeo had excommunicated the previous governor, Luis de Requesens y Zúñiga, over the issue of Borromeo's personal police force. The new governor was faring little better, clashing with the cardinal about everything from religious ceremonies to urban development projects. ${ }^{1}$ For the second year in a row, the governor gave orders for the traditional Carnival performances in which he would also take part. Once again, Borromeo responded by publishing an act threatening excommunication for all participants, which Ayamonte proceeded to ignore soundly. It piqued the Ayamonte's anger when the newly-excommunicated flocked to the cardinal, seeking his absolution, including some of the governor's personal guests. On 1 March 1580, perhaps intending retribution, but certainly the final word, Ayamonte ordered the raid and closure of the cardinal's seminary print shop, jailing its printers. ${ }^{2}$

Historians have often approached the crisis of 1579/158o from a biographical perspective, emphasising the conflict between the Spanish governor's adherence to courtly protocol and martial hierarchy, and Borromeo's own uncompromising devotion to recreating the Ambrosian church. ${ }^{3}$ The raid on the

1 Many miscellaneous documents related to these conflicts and the earlier excommunication survive in the buste of the Archivio di Stato di Milano (ASMi), Atti di governo, Culto. See particularly busta 558 .

2 This incident has been treated by Kevin Mark Stevens, Printers, Publishers and Booksellers in Counter-Reformation Milan: A Documentary Study (University of Wisconsin, Unpublished PhD dissertation, 1992) and his 'Printing and Politics: Carlo Borromeo and the Seminary Press of Milan', in Nicola Raponi and Angelo Turchini (eds.), Stampa, libri e letture a Milano nell' età di Carlo Borromeo (Milan: Vita e Pensiero, 1993), pp. 97-133.

3 The Storia di Milano series mirrors a traditional division between political and religious authority in Milan's sixteenth-century in its division of two volumes of relevance: Federico Chabod, Storia di Milano: L'epoca di Carlo V (1535-1559) (Milan: Fondazione Treccani degli Alfieri per la Storia di Milano, 1961) and Mario Bendiscioli, Storia di Milano: L'età della reforma cattolica (1559-1630) (Milan: Fondazione Treccani degli Alfieri per la Storia di Milano, 1956). 
seminary press escalated tensions, but it also demonstrated the joint evolution of secular and religious authority in Milan; both recognised the importance of the press for governing daily life in the city. From the printed edicts that brought about the crisis, to official anthologies of legislation (acta and gridari), to the use of printed tickets (bolletini) to license and record commerce, print was the chosen medium for exercising social control in late sixteenthcentury Milan. ${ }^{4}$

The plague years of ${ }^{1576-78}$ were particularly crucial for the development of official print production in Milan, and provide key foregrounding for the crisis. Static statements about Spanish or Borromean Milan elide the enormous changes between 1540 and 1590. San Carlo Borromeo, canonised in 1610, casts a particularly long shadow. For many contemporaries, the Ambrosian library and seminary press perfectly joined humanist inquiry and Catholic catechesis; conflict with Spanish authorities makes the story all the more miraculous. The cardinal and governor shared a goal of quelling social dissent in Lombardy, which before the 1570s, seemed plagued by would-be heretics and traitors. Tools for social control developed in conjunction with interventions in the name of public health during the 156 os and 1570 . The combination of powerful rhetoric and printed authority furthered a contagion theory of dissent, and a top-down method of prevention, quarantine, and treatment.

For an example of works bridging the gap, see Agostino Borromeo, 'Archbishop Carlo Borromeo and the Ecclesiastical Policy of Philip II in the State of Milan', in John Headley and John Tomaro (eds.), San Carlo Borromeo: Catholic Reform and Ecclesiastical Politics in the Second Half of the Sixteenth Century (Cranbury/ London/Mississauga: Associated University Presses, 1988), pp. 85-111; Paolo Pissavino and Gianvittorio Signorotto (eds.), Lombardia borromaica, Lombardia spagnola: 1554-1659 (Rome: Bulzoni, 1995).

4 I have chosen to use 'social control' here as I wish to emphasise the gathering and publication of social informatics that did not always result in active discipline, however I owe much to the ample social discipline literature. Wietse de Boer carries out a particular fruitful application in his study of Carlo Borromeo's confessional program in his The Conquest of the Soul: Confession, Discipline, and Public Order in Counter-Reformation Milan (Leiden: Brill, 2001). See also Danilo Zardin, 'La "perfezione" nel proprio "stato": strategie per la riforma generale dei costume nel modello borromaico di governo', in his Carlo Borromeo: cultura, santità, governo (Milan: Vita e pensiero, 2010), pp. 105-142. Gianvittorio Signorotto takes a similar approach to a propagandising use of print in Milan, but puts greater emphasis on the secular use of military threat in his article 'Milano nella guerra dei Trent'anni: Informazione politica, mobilitiazione, conflitti', Rivista storica Italiana, 130 (2018), pp. 895-918. 


\section{Duchy and Diocese to 1576}

At the beginning of the sixteenth century, the duchy of Milan was enormous, and the diocese even larger. The duchy stretched from Genoa and the Ligurian sea in the South to Lake Como and the foothills of the Alps to the North. It effectively monopolised passage along the river Po. The diocese included swaths of politically Savoyard, Swiss and Venetian territory. The city of Milan had the fourth-largest population in Europe, and its commercial strength made it a valuable prize. ${ }^{5}$ Dominance over Milan had been one of the most contentious points of the century-long Italian wars. After the 1535 death of the last Sforza duke, the duchy passed into Habsburg hands, ruled first by Charles v, then entrusted to his son, King Philip II of Spain.

Circumstances were ripe for political rebellion in the 1540 os and 1550s, and there were several close calls. In 1544, Spanish authorities imprisoned members of the local Milanese elite on charges of conspiracy. In 1548, Giulio Cibo Malaspina was brought to Milan and sentenced to death for a plot to deliver Genoa to French. ${ }^{6}$ Spanish authorities were convinced that such dissent was habitual for their Lombard subjects. When the Duke of Alba arrived in Milan as governor in 1555 , he wrote with disgust, "here there is a custom that seems very bad to me, of speaking far too liberally whether one is for the Imperial or French, like they speak in Rome and Venice, and of treating publically the actions and choices of state officials, as though they were not their lords.7 Despite such complaints, royal attention focused on uprisings in the Spanish Netherlands, and governors were moved frequently further North. While Governor Ferrante Gonzaga (o. 1546-1554) had been from nearby Mantua, the Duke of Alba (o. 1555-1556) and many successors were members of the Castilian elite. They lived removed from their Milanese Italian subjects, surrounded by Spanish forces in the districts around the castle and other military installations. ${ }^{8}$ By all accounts, Milan was a loose cog in the imperial apparatus.

Milan's unique position as a communication and commercial hub contributed to the contentious public sphere. Lombardy bordered the strange Swiss political entity known as the Grey League, or the Grisons, by way of a subject

5 Stefano D'Amico, Spanish Milan: A City within the Empire, 1535-1706 (New York: Palgrave Macmillan, 2012), pp. 1-6.

6 Accused conspirators included Camillo, Alessandro, Giovanni Battista and Lancelloto Castiglioni. Chabod, Storia di Milano, p. 157.

7 Letter by Duke of Alba to Ruy Gomez de Silva on 28 October 1555 quoted in Chabod, Storia di Milano, p. 156.

8 D'Amico, Spanish Milan, pp. 7-34. 
region known as the Valtellina, which consisted of several densely populated valleys, and the cities of Chiavenna and Morbegno. Contemporaries frequently described the relative political and religious freedom of the region as heretical and anarchical. ${ }^{9}$ Concerns often mixed the potential for religious and political rebellion: in October of 1572, Governor Luis de Requesens y Zúñiga (o. 1572-1573) called the Swiss and Grisons 'very rebellious in their houses, and very preoccupied with bringing the King of France into their domain', while the Spanish ambassador to Trent, Juan Vargas Mexia, wrote of a vast Protestant conspiracy across Northern Italy. ${ }^{10}$ However as the figures of individual reformers such as Agostino Mainardo and Pietro Vergerio demonstrate, evangelical preaching, utopian idealism, and egalitarianism in politics and religion held a powerful inherent appeal. ${ }^{11}$

Carlo Borromeo was appointed to the archiepiscopacy of Milan at the age of 22 in 1560. He remained abroad, aiding his uncle Pope Pius IV in Rome, and playing a key part in the final session of the Council of Trent in 1562. It was only upon the 1566 succession of Pius $\mathrm{v}$ that Borromeo fully relocated to Milan (then the most populous diocese in Europe) and began his career in earnest as the successor to St. Ambrose. ${ }^{12}$ Within his archdiocese, Borromeo demonstrated a wholehearted commitment to the eradication of heresy. Yet for every institutional achievement, there was often a setback associated with his uncompromising approach. In his first years in Milan, Borromeo toured the Northern reaches of his archdiocese and caused such a diplomatic incident in the Valtellina that he barely fled arrest. ${ }^{13}$ A decision to disband the Umiliati order nearly had fatal results in 1569 , when a former member ambushed Borromeo in his private chapel. That same year, the canons of Santa Maria alla Scala barred Borromeo's entry in protest to what they saw as unwarranted power-mongering. Borromeo encountered strong resistance from the Spanish governors, particularly the Marquis d'Ayamonte (o. 1573-1580), who found

9 Randolph Conrad Head, Early Modern Democracy in the Grisons: Social Order and Political Language in a Swiss Mountain Canton, 1470-1620 (New York: Cambridge University Press, 1995).

10 Letter by Luis de Requesens y Zúñiga to Philip II on 28 October 1572 included in Domenico Maselli, Saggi di storia ereticale lombarda al tempo di S. Carlo (Naples: Società Editrice Napoletana, 1979), appendix, pp. 200-201; Letter by Juan Vargas Mexia written to the Duke of Albuquerque on 3 October 1570 quoted in Maselli, Saggi di storia ereticale, p. 54.

11 Agostino Borromeo and Quintín Aldea Vaquero (eds.), La Valtellina crocevia dell'Europa: Politica e religione nell'età della Guerra dei Trent'Anni (Milan: G. Mondadori, 1998).

12 Michel de Certeau, 'Carlo Borromeo, Santo', Dizionario biografico degli Italiani (DBI), v.2O (Rome: Istituto della enciclopedia italiana, 1977), p. 262.

13 Henry Charles Lea, The Inquisition in the Spanish Dependencies (New York: Macmillan, 1922), p. 130. 
the archbishop arrogant and disrespectful. In these early years, the relatively young reformer seems to have generated more resistance than change.

Like their secular counterparts, Milan's Archbishop and Inquisition saw foreign influences as the main source of heretical thought. Merchants from abroad were subject to particular suspicion as potential couriers ferrying contraband letters and books, or as being missionaries in disguise. A 1563 letter from the Venetian secretary in Milan described how the inquisitors sought heretics along the borders of the Swiss and Grisons, who are a type of merchant sent throughout the world with secret intelligence and correspondences, not just related to their business, but to take up arms and rise against their princes ...'14 Giorgio Guerzi was captured on just such charges in 1568 , as was Giacomo Torricelli in 1575, who appeared to carry with him a map of safe houses for missionary activity throughout Italy. ${ }^{15}$ In a 1569 oration, Borromeo compared the walls of Milan to floodgates, barely withstanding outside pressure. ${ }^{16}$

Both religious and Spanish authorities displayed a constant anxiety about the social and religious stability of the Lombard region in the years before 1576 . However, both groups were fundamentally limited in their ability to control influence from abroad. Governor Gonzaga had submitted plans for the conquest of the Valtellina, Bergamo, and Brescia, but his Spanish superiors were more invested in keeping the peace; they mandated the greatest prudence in diplomatic relations. ${ }^{17}$ The Inquisition, while maintaining that any transaction with heretics, commercial or otherwise, constituted heresy, lacked essential secular support for enforcement. ${ }^{18}$ Treaties between Milan and the Grisons guaranteed mercantile rights. As the Milanese representative Ascanio Marso summarised 'they come, stay, return, negotiate and traffic in Milan freely and securely regardless of the prohibition, as long as they do not have and sell

14 Letter by Antonio Mazza to the Council of Ten on 3o March 1563 quoted in Maselli, Saggi di storia ereticale, p. 33.

15 Letter by Giovanni Ricci, Cardinal of Pisa, to Cardinal Borromeo on 4 September 1568 included in Maselli, Saggi di storia ereticale, appendix, p. 162; Letter by Cardinal of Pisa to Cardinal Borromeo on 14 May 1575 in Maselli, Saggi di storia ereticale, appendix, p. 171.

16 'Cultivating the field persistently. Oration at the second provincial council, April 24, 1569' translation from Carlo Borromeo, John R. Cihak (ed.), Ansgar Santogrossi (trans.), Charles Borromeo: Selected Orations, Homilies and Writings (London/Oxford/New York: Bloomsbury Publishing, 2017); Borromeo's approach echoed that of his predecessor in portraying heresy as an external enemy, see Michael Stuart Williams, The Politics of Heresy in Ambrose of Milan: Community and Consensus in Late-Antique Christianity (Cambridge: Cambridge University Press, 2017).

17 Gonzaga also was an early exponent of closed borders as an anti-plague measure, which he put into effect in 1549. See Chabod, Storia di Milano, pp. 170-174.

18 Lea, The Inquisition, p. 173. 
[prohibited things], nor wish to dispute the faith or bring books against the Old Religion.' ${ }^{19}$ This provided cold comfort to Spanish and religious authorities, who noted how commonly the Milanese collected foreign works in their libraries and corresponded with known heretics. ${ }^{20}$

The Inquisitors persisted but met constant popular resistance. In 1563, Philip II tried unsuccessfully to introduce the Spanish Inquisition to Milan. There was public outcry, and a full embassy of Milanese delegates arrived at the Spanish court to lodge a formal protest. ${ }^{21}$ A story from the life of Fra Michele Ghislieri (later the notorious Pope Pius v) represents many common stories from these years. Ghislieri was working as an inquisitor in the duchy of Milan when he stopped a consignment of heretical books at the customs house on their way to Como. The merchant complained to the sympathetic episcopal vicar, who took possession of the books despite Ghislieri's protests. Ghisleri brought the case before the Roman Holy Office, who demanded that the vicar and canons appear. The local clergy, in turn, involved governor Gonzaga. When Ghislieri set out to appear before the governor, he narrowly escaped a murderous ambush. ${ }^{22}$ Other Dominican friars were not so fortunate: a number were assaulted and killed in Mantua in 1567, accused of having been overzealous in aiding the Inquisition. ${ }^{23}$

19 Marso himself is a fascinating figure; sent by Gonzaga to Basel to report on the Italian Protestant community there, he acted as a double agent to hinder negotiations between the Grisons and French. He appears to have run a network of spies throughout the region in service to the duchy of Milan, but he came under fire for corresponding with the reformers of Zurich and Chiavenna in the course of the late 1550s, resulting in his arrest on 6 March 1559. Marso was pardoned, but the incident reveals the level of mutual suspicion and miscommunication in Milanese governance. Letter by Ascanio Marso to the Senate and Grand Chancellery on 13 April 1555 in Chabod, Storia di Milano, p. 174.

20 Agostino Mainardo notably corresponded with the monks of Milan's San Marco. Simonetta Adorni Braccesi and Simona Feci, 'Mainardo, Agostino', DBI, v. 67 (Rome: Istituto della encyclopedia italiana, 2006), pp. 585-59o; Meanwhile Kevin Stevens demonstrates that Milanese booksellers maintained substantial debts to Venetian publishers, clearly purchasing works in bulk. His study of seven retailers' book inventories finds works condemned by the 1559 Index present across the board. Stevens, 'Printers, Publishers, Booksellers', pp. 183-185, 226; See also the confiscation of Conte Robbio's library in a letter written by Cardinal of Pisa to Cardinal Borromeo on 14 May 1575 quoted in Maselli, Saggi di storia ereticale, appendix, p. 171.

A 1563 letter to the Governor instructed him to behave as though the idea had never been entertained. Philip II to the Duke of Sessa, 'Abandoning the Introduction of the Spanish Inquisition in Milan' 8 November ${ }_{15} 63$ in Lea, The Inquisition, appendix, p. 529. Originally cited from Archivio Civico Storico, Armario A, filza viI, n. 40. 
Most of the records of the Milanese Inquisition have been lost, destroyed in more recent centuries. Yet many anecdotal cases such as this can be supplemented by the secular and ecclesiastical archives of Milan to present an overall picture prior to the plague years: jurisdictional obstreperousness, repeat offenders, and daring escapes ran rampant. ${ }^{24}$ Several attempts were made to restructure the inquisition in Milan. ${ }^{25}$ The deeper problems, however, went unaddressed: the persistent resistance of locals, and the difficulty of controlling cross-border transit and exchange, particularly given the tricky position of the Milanese diocese within foreign polities. ${ }^{26}$

From 1500-1560, the Spanish Duchy of Milan was a highway for heresy rather than a bastion of Catholicism. Its location at a communications and transport waypoint brought constant traffic of people, texts and ideas, which cross-pollinated with local heterodoxy and political allegiances. The duchy was a rich garden for intellectual diversity and institutional criticism. The Milanese, in particular, grew used to freedoms derived from the diplomatic stalemate with the Swiss North and Venetian East. As noted by the Spanish governors, the people vocalised their personal stake in politics and were more likely to bow to the bonds of family and locality than to their foreign rulers or inquisitors. As the Cardinal of Pisa wrote of one soldier brought before the Inquisition to provide information on his noble patrons, 'he professes to believe that testifying against another is a thing of little honor'. ${ }^{27}$ No doubt many locals, including the clergy, held similar beliefs.

24 See for further example, the case of the Augustinian friar Claudio de Pralboino, convicted for apostasy, who escaped with forged papers of pardon in 1556. Cases such as the burning of Francesco Cellaria, a Valtelline missionary who made frequent visits to noble patrons in Mantua, were rare successes, with extradition achieved through a combination of subterfuge and brute force. Lea, The Inquisition, pp. 124, 134-135.

25 Including taking the responsibility from the Dominicans of San Eustorgio and investing instead those of Santa Maria delle Grazie in 1558.

26 As shown by Paul Grendler's seminal study, the Venetian relationship with the Roman Inquisition was grudging at best, and more often opted for protectionist policies in favor of its universities, religious institutions, and printing industry. Paul F. Grendler, The Roman Inquisition and the Venetian Press, 1540-1605 (Princeton: Princeton University Press, 1977).

27 Letter by Cardinal of Pisa to Borromeo on 31 July 1571, in Maselli, Saggi di storia ereticale, appendix, 168-169. 


\section{Years of Pestilence (156o-1578)}

The 'Caroline' plague in Milan shifted relations between the state, the church, and the Lombard people. ${ }^{28} \mathrm{~A}$ confessionalising and territorialising agenda, previously met with ample resistance, achieved new success. The emergency circumstances created by the plague provided new impetus for the development, implementation and acceptance of new social controls. The threat of plague was tied to a powerful new presence of ecclesiastical and secular governance in peoples' lives through print. The use of printed edicts and tickets to manage a distributed network of officials, communicate to the public, and underscore authority was an important administrative innovation.

The plague first appeared around Trent in the early 1570s, spreading to Milan by July 1576. It followed several hard years of famine and sporadic outbreaks of what was likely influenza. As of 1574 , the population of the city was around 115 ,000. Some estimates put the following plague deaths at nearly 25 ,000 or $18-20 \%$ of the population. ${ }^{29}$

Located as it was at the crossroads of Europe, Milan was no stranger to plague. Duke Bernabo Visconti had promulgated one of the earliest set of plague quarantine laws in Europe in the 1370s, while Giangaleazzo Visconti put in place a comprehensive notification scheme involving mandatory reporting to parish elders. In 1535, Duke Francesco Sforza II introduced the office of public health (Magistrato di sanità). ${ }^{30}$ The office depended upon deputised functionaries (often clergy) across Lombardy to keep them apprised of any suspicious persons (particularly vagabonds), register the dead, and report on the hygiene and security of street and sewage systems. Early contagion theory dictated that the ill be identified, then isolated from the general community, along with all members of their household. ${ }^{31}$

28 So named after Carlo Borromeo to distinguish it from that of 1630 , which occurred during the office of Federico Borromeo (1564-1631).

29 Population estimates taken from D'Amico, Spanish Milan, p. 12. Plague death estimates often based on two chroniclers, Giacomo Filippo Besta put it at 17,329, while Gaspare Bugato wrote 18,320; Giacomo Filippo Besta, Vera narratione del svccesso della peste, che afflisse l'inclita citta' di Milano, l'anno 1576. \& di tutte le prouisioni fatte à salute di essa città (Milan: Da Ponte, 1578), ustc 814306; Gaspare Bugati, I fatti di Milano al contrasto della peste, over pestifero contagio: dal primo d'Agosto 1576, fin a l'ultimo dell'anno 1577 (Milan: P. Gottardo, \& Pacifico Pontij, fratelli, 1578), USTC 817140.

30 The body was composed of a president and secretary chosen from among the Senate, four conservators, including two investigators and two doctors, and a jurisconsultant. See Giorgio Cosmacini, Il medico e il cardinale (Milan: San Raffaele, 2009).

31 Ann Carmichael, 'Contagion Theory and Contagion Practice in Fifteenth-Century Milan', Renaissance Quarterly, 44:2 (1991), pp. 213-56. 


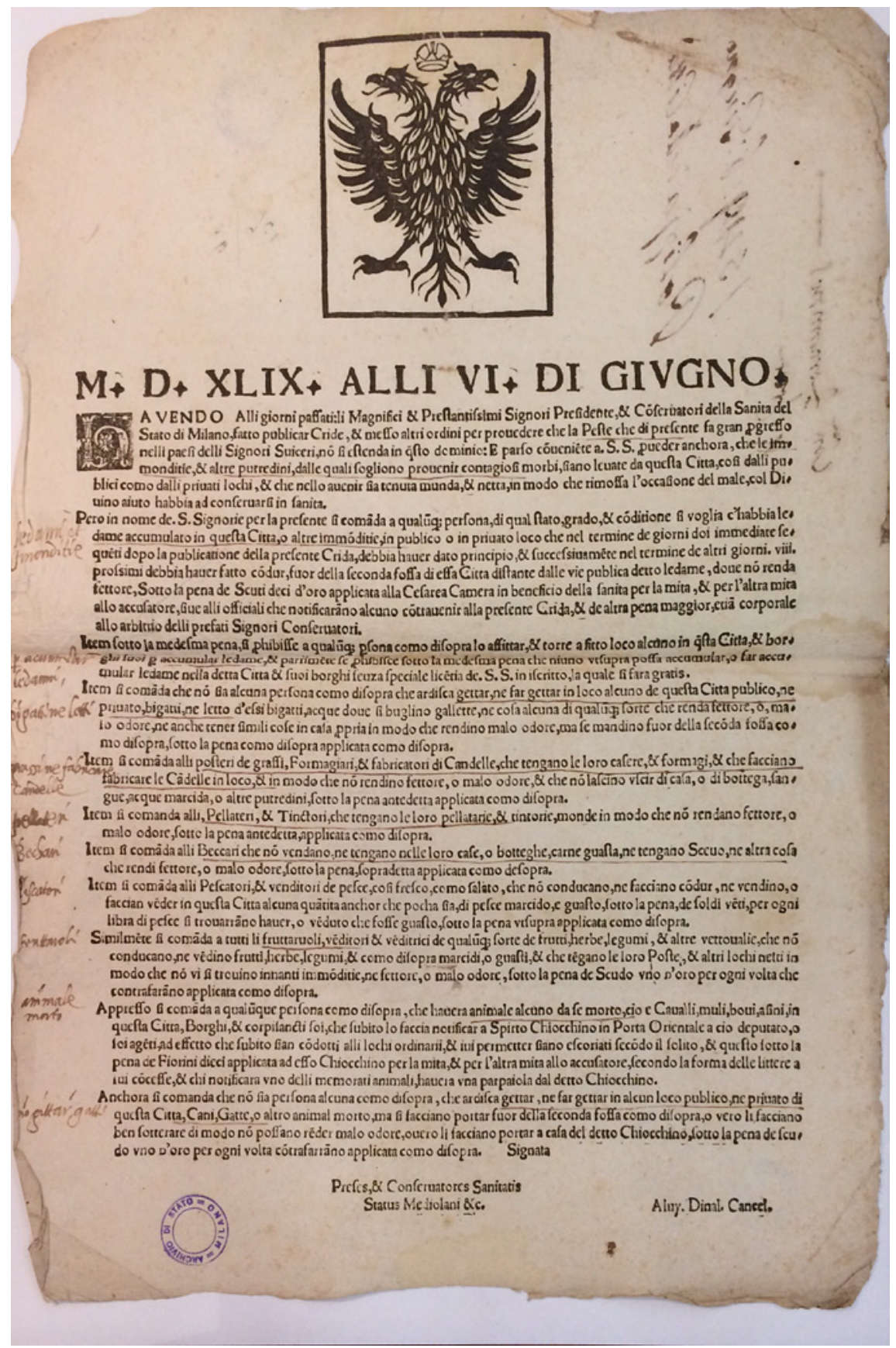

FIGURE 1.1 Edict of 6June 1549 ASMi, Atti di governo, Sanità parte moderna, busta 3 REPRODUCED WITH PERMISSION OF THE ARCHIVIO DI STATO DI MILANO 
The earliest print public health edict (grida) in the collection held by the state archive in Milan (ASMi) dates to 1549 [Fig. 1.1]. ${ }^{32}$ The printing is crude, with a simple woodblock of the double-headed Habsburg eagle. The edict mandated several standard preventative measures: the clearing of waste in public and domestic spaces and the general eradication of 'bad odor' associated with the plague, particularly from trades such as cheesemakers, candle makers, and tanners.

By the next 1563 example, the plague edicts had a much more refined style [Fig. 1.2].33 They were printed with the arms of King Phillip II, and joined by the signatures of the President and Conservator of Public Health at the bottom. This and several other examples use a particularly appropriate visual metaphor for the social control: a woodblock letter featuring a woman switching a bare-bottomed man [Fig. 1.3]. Readers were warned of the advent of 'several miserable, nefarious enemies to human nature' from the Piedmont who with 'unctions, dusts and other diabolical arts aim to spread plague across the land'. ${ }^{34}$ They were even given the power to 'shoot or wound with impunity' any such unwelcome visitor. Later in 1576, Governor Ayamonte clarified that he did not really believe the 'unctioner' theory, but did think that foreign troublemakers sought to rile the credulous. ${ }^{35}$

What can the development of the plague edicts tell us about the use of official print in 1570 o Milan? First, we see that they were shaped by a particular socio-cultural moment, from the employment of broadsheet-style sensationalism to the emphasis on vigilante response. By 1576 , the Marquis d'Ayamonte's name and coat of arms featured prominently, while the text referenced the 'diligence and pastoral care of the Reverend Cardinal and Archbishop' (notably not naming Cardinal Borromeo). The authorities mutually affirmed one another, while the governor nonetheless asserted his pre-eminence. The figurative presence of the governor covered for his physical absence, as the

32 ASMi, Atti di governo, Sanità parte moderna, Busta (b.) 3, Edict (6 June 1549).

33 ASMi, Atti di governo, Sanità, b. 3, 'Quelli portanto untioni et altre cose per portar la peste' (12 September 1563).

34 'Essendo avisati l'Illust. \& Mag. Signori Presidente, e Conservatori della Sanità del Stato di Milano, come nella Città d'Ast, Verceli, Alessandria \& Casale, \& altri luoghi del Piemonte, \& di questo Dominio, di nuovo denno esser gionti certi tristi, nefandi, \& nemici della humana natura, che con loro untioni, polvi, \& altre arti diaboliche, vanno spargendo la pese sopra della terra ...' ASMi, Atti di governo, Sanità, b. 3, 'Quelli portanto untioni et altre cose per portar la peste' (12 September 1563).

35 MS copy of decree from Ayamonte (12 September 1576), ASMi, Registri delle cancellerie dello stato, b. 16 . 


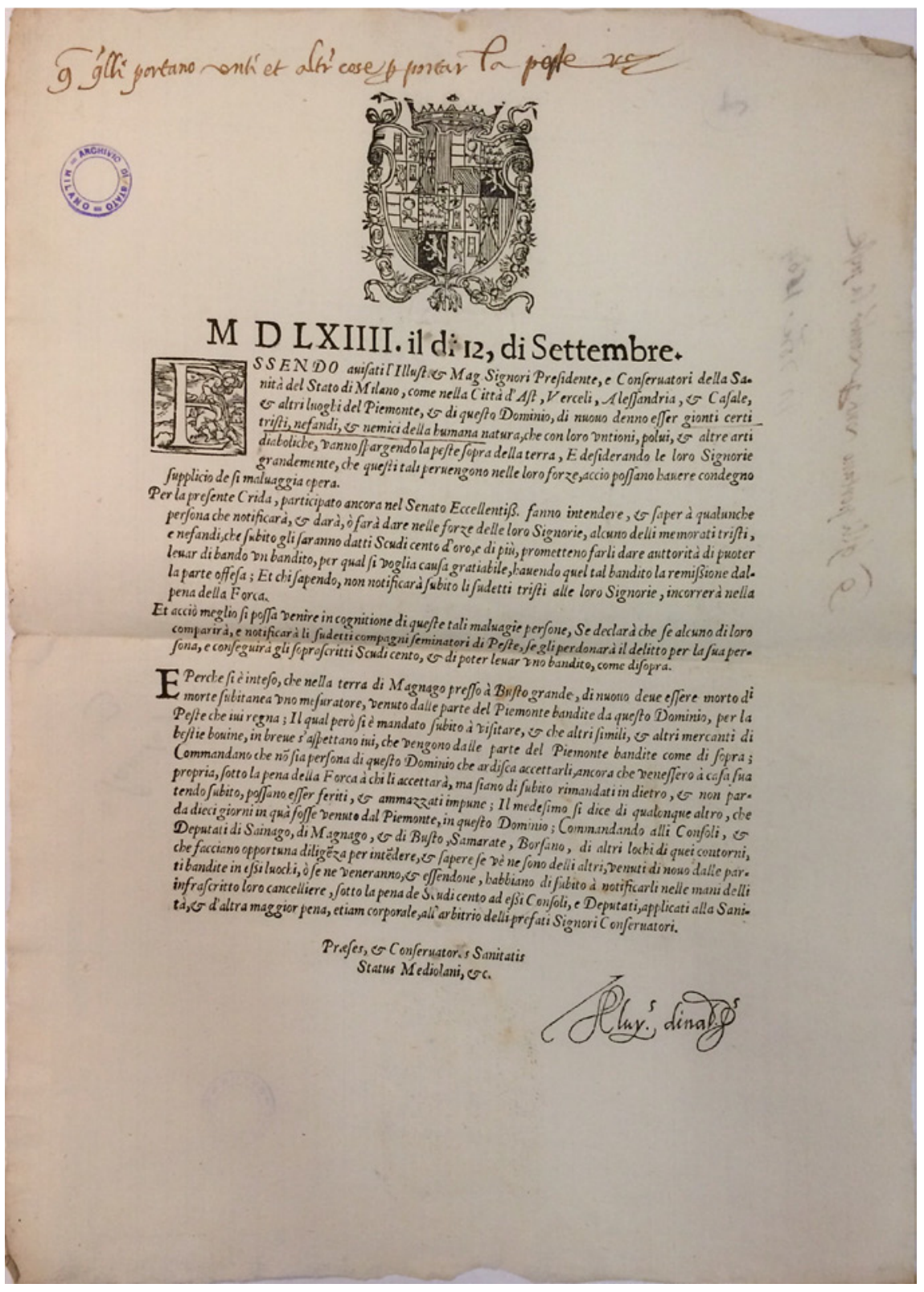

FIGURE 1.2 Edict of 12 September 1563 ASMi, Atti di governo, Sanità parte moderna, busta 3 REPRODUCED WITH PERMISSION OF THE ARCHIVIO DI STATO DI MILANO 


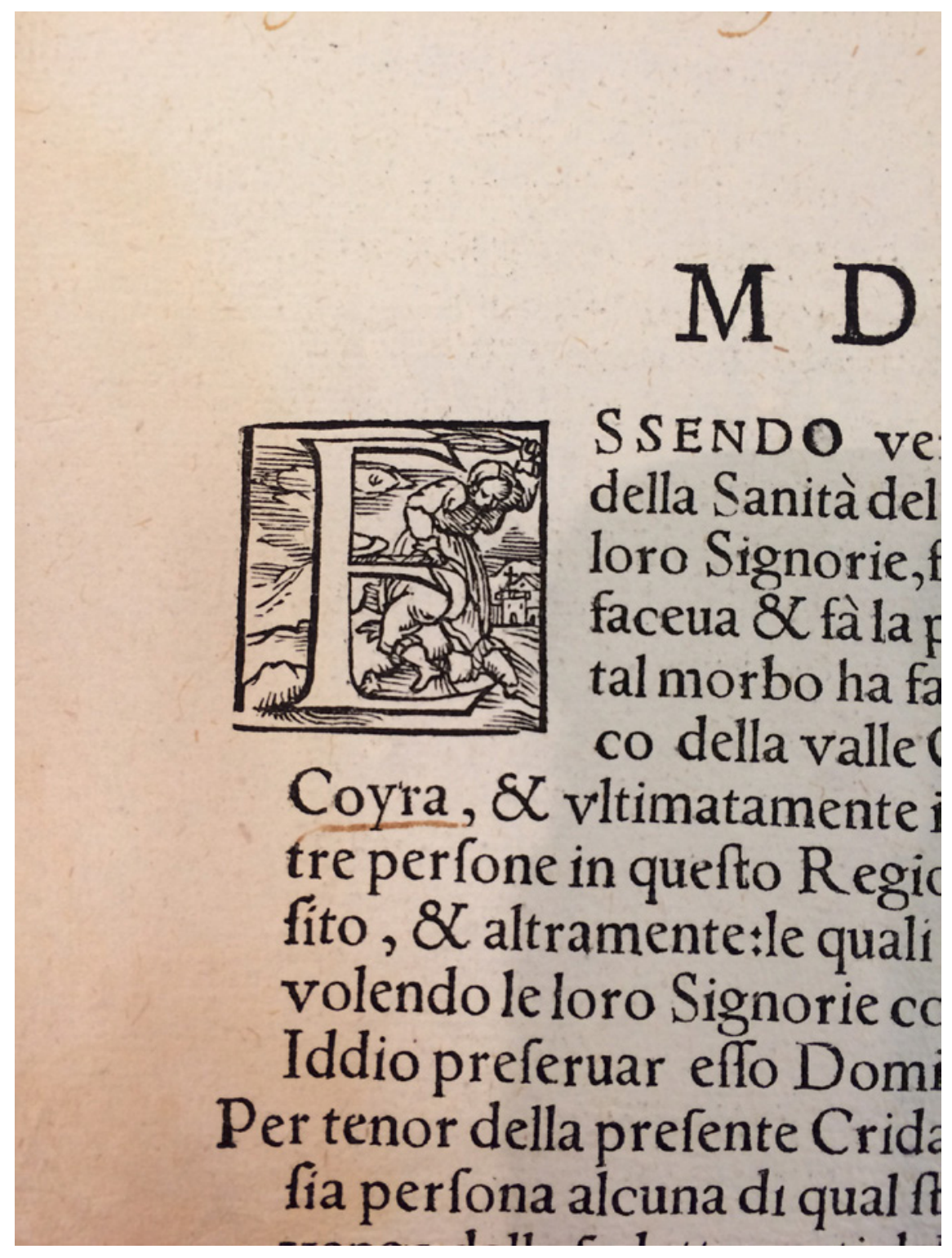

FIGURE 1.3 Detail of Edict of 12 September ${ }^{1563}$ 
Marquis had fled the onset of the plague. ${ }^{36}$ By the autumn of 1576 , such edicts were appearing at least weekly, even given what are likely poor survival rates. ${ }^{37}$ The department of public health began to employ its own printers, Pacifico and Giovanni Battista Pontio, who developed a consistent aesthetic joined with the revision and reprinting of boilerplate language. ${ }^{38}$ These print communications could be cautionary, punitive, instructional, and even referential, providing the days and times for household inspections and names of deputised inspectors. The development of a consistent print program was part and parcel of a larger bureaucratic protocol to respond to the plague, which by necessity involved the public as participants and enforcers. Edicts were included in letters with orders to hang them in public places, thereby distributing them across a wide network of administrators. In Milan, they were often posted at the city's many gates. One manuscript version was stitched together to be unfolded in a scroll-like fashion, indicating the ongoing interplay between aural, manuscript and print modes. ${ }^{39}$

It is difficult to reconstruct the reception of the edicts, but their content certainly became more restrictive as the situation grew dire. Citizens of Milan were regularly under general quarantine between $1576-1578$, with movement and gathering completely banned for suspect or vulnerable groups. ${ }^{40}$ The edicts themselves preserve some of the back-and-forth between the public and governing authority. They addressed individual rumors, such as that of the unctioners, chastised remiss officials, and increasingly threatened the death penalty for disobedience. Attention was mandatory, as several provided deadlines for altered behavior declared, pre-emptively discounting claims to ignorance

36 His absence was noted by contemporaries; On 29 September 1576, Papirio Picedi commented that the 'the marquis of Ayamonte has been invisible'. Quoted in A. Valente, 'La peste del 1576 in Milano. Notizie tratte dalle lettere di un contemporaneo', Archivio Storico Lombardo, 5 O (1923), p. 458.

37 See edicts of 19 October, 23 October, 25 October, 26 October and 4 November in ASMi, Atti digoverno, Sanità, b. 3.

38 The earliest signature by one of the Pontio brothers as printer for the Sanità is Pacifico Pontio on an edict from August 1572; Gio. Battista does not appear using the title of printer for public health specifically until 1577. In ASMi, Atti di governo, Sanità, b. 3; Pacifico and Gio. Battista would also come to play an important part as printers for the seminary press, some of whom were jailed for printing materials without the license of the Inquisition. Stevens, Printers, pp. 234-235.

39 Printed grida (2 August 1577) in ASMi, Atti di governo, Sanità, b. 3.

40 Cosmacini indicates that an overall ban was only applied to women and children, but that the movement of groups such as artisans who traveled between districts was restricted. Cosmacini, Il medico, p. 77 . 
or inability ('which is not to be believed'). ${ }^{41}$ Manhunts for specific individuals who escaped confinement are particularly striking: see one such example seeking a 'Giovanni Spagnuolo' and providing a detailed physical description. ${ }^{42}$ Proscriptive sources are a distorted mirror for reality at best. The propagandising power of such an all-seeing, all-knowing performance still rings true today. In fact, the edicts were later reprinted as bound volumes (gridari), editions of which can be found in several major collections. ${ }^{43}$ They modeled a highly interventionist role for government in the lives of the Milanese people.

As the printing of state edicts became a weekly occurrence in October of 1576, Cardinal Borromeo led a procession through the streets, barefoot and carrying a crucifix. He conducted several such processions over the next months (including one with 1,ooo disciplinati who flagellated themselves) and offered plenary indulgences to all participants. He frequently ministered to victims in person at the largest plague hospital, the Lazzaretto, his presence a stark contrast to the absent governor, or the Jesuit Provincial Francesco Adorno, who refused to send his priests to accompany the archbishop. The later importance of the plague ministry to Borromeo's personal narrative and eventual canonisation is visible in the four enormous Quadroni that hang in the Milanese cathedral. ${ }^{44}$ In many Borromeo is shown resplendent in his cardinal's robes, surrounded and lauded by the plague's many victims. The mannerist perspective places the viewer among the populace, looking up at the heroic figure astride his white horse [Fig. 1.4]. ${ }^{45}$

However, Borromeo never lost his crusader's passion against heretical dissent. A 1572 act from the cardinal charged heretics with 'seducing' many, and 'devouring the Lord's flock like rapacious wolves'. 46 The act provided a list

41 Printed tickets with blanks for Ms addition (30 July 1577) in ASMi, Atti di governo, Sanità, b. 3 .

42 'Per la Fugga d'un Carcerato dal luogo del lazzeretto di Mil.o in tempo di contaggio' (23 March 1578) in ASMi, Atti di governo, Sanità, b. 3.

43 Ascanio Centorio de'Hortensii, I cinque libri degl'avvertimenti, ordini, gride, et editti: fatti, et osservati in Milano, ne'tempi sospettosi della pesta (Venice: G.P. Gioliti de' Ferrari, 1577), USTC 821598. Later reprinted in Milan by Gio. Battista Bidelli in 1631, USTC 4010158.

44 Borromeo's embrace of print also fits within his overall attention to visual media as a means of cultivating devotion. See Grace Harpster, Carlo Borromeo's Itineraries: The Sacred Image in Post-Tridentine Italy (University of California Berkeley, unpublished PhD dissertation, 2018).

45 Pamela Jones, 'San Carlo Borromeo and Plague Imagery in Milan and Rome', in Gauvin Alexander Bailey (ed.), Hope and Healing: Painting in Italy in a Time of Plague, 1500-1800 (Chicago: University of Chicago Press, 2005), pp. 65-96.

46 'Editto Che Si Denunciino Heretici ...' (1572) in Carlo Borromeo, Pietro Galesino (ed.), Acta Ecclesia Mediolanensis tribus partibus distincta (Milan: Pacificum Pointium, 1582), USTC 842632, col. 1104. (Henceforth: AEM). 


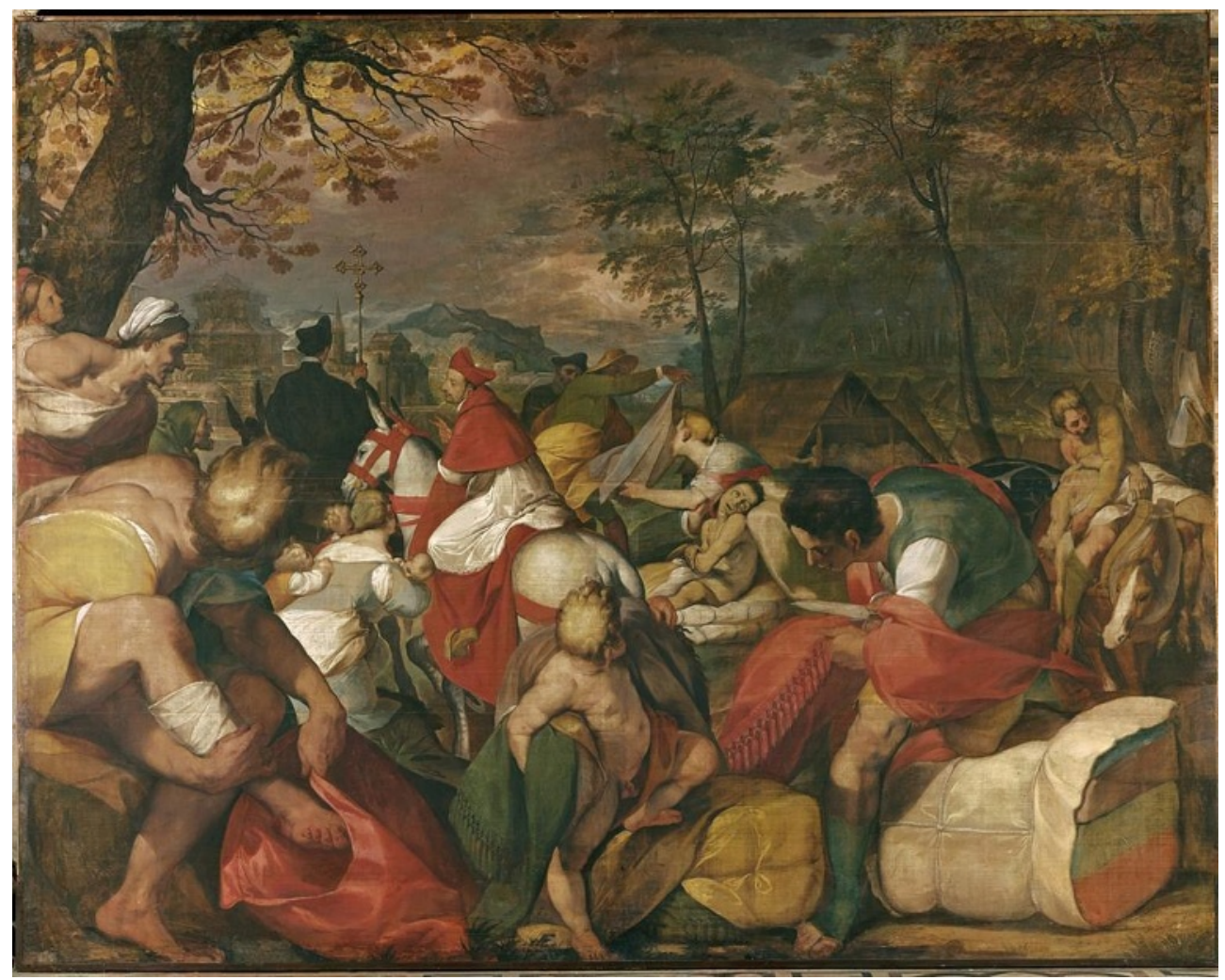

FIGURE 1.4 Giovanni Battista Crespi (Cerano), San Carlo Borromeo consola gli appestati alle capanne (1602). Hung in the Duomo of Milan as a part of a series of scenes from the life of San Carlo Borromeo REPRODUCED WITH PERMISSION OF THE FONDAZIONE ZERI

of heretical words and acts; infamous men and their helpers, defenders, and believers; and heretical texts, all of which could contaminate a believer. Any contact required speedy denunciation to the diocese or inquisitor on pain of excommunication. The act declared the need for 'a common vigilance for the sake of common health' uniting the people against 'the common enemies.' ${ }^{47}$ We see also here an early reference to the spiritual 'health' of the community, a theme that Borromeo would develop more fully in the coming years.

The comprehensiveness of Borromeo's reform program, and the later emphasis on print publication, provides us with ample evidence to analyze the progression of his ideology and rhetoric across his career. His sermons and other writings circulated widely in print, even prior to their collection in his

47 'Editto Che Si Denunciino Heretici ...' (1572) in AEM, col. 1101-1102. 
1582 magnum opus: the Acta Ecclesia Mediolanensis. ${ }^{48}$ The Acta consist of the many decrees and orations of six provincial councils and eleven diocesan synods called by the Cardinal, as well as a selection of other acts and writings. The project and its contents speak to the strong influence of Tridentine reform on Borromeo's program. As the edict collections represented the Spanish government, so too did the Acta convey Borromeo's confessional program at home and abroad.

Many entries show the impact of the plague years quite directly, none more so than the acts of the fifth provincial council of Milan. ${ }^{49}$ Beginning with 'On Plague Ministry', Borromeo provided clergy with practical precautions derived from his experience. He instructed the clergy in the correct process for determining 'what, and how much is the power of the plague; how dire is the infection; how much, and what varieties of havoc it causes; how much and how terrible are the its causes, how suddenly it takes the soul to the tremendous judgement of Christ The Lord'. 50 In Borromeo's rhetoric, the health of the physical body was constantly linked to the health of the spiritual body. He warned priests of the effect the plague might have on even the faithful: 'the soul is move to panic, and made emotional and bewildered. ${ }^{51}$ While cautioning clergy to take 'prudent precautions' he nonetheless heartily endorsed public services and demonstrations, lest stations go untended and souls unministered (a position that notably put him at odds with the Spanish authorities)..$^{52}$

Borromeo cultivated this rhetorical link between physical and spiritual pestilence over the course of the plague years, reaching a particularly refined form in his 1579 "Letter to the People of Milan." ${ }^{53} \mathrm{He}$ blamed the plague on the 'provocations to God' posed by the pagan celebrations of carnival, and the pride and vanity of the Milanese people. 'And when you find fever', Borromeo now instructed the patients, rather than the care-givers, 'it is not enough for a Christian to seek the cause in the humors intrinsic to the body, and the putrefaction that they produce, but he must look up to see with Christian light of reason what causes have moved God to permit and maintain such a fever. ${ }^{54}$ Like doctors, victims also needed to be wary that not fully cured, spiritual

\footnotetext{
48 See footnote 46. Republished in 1599 with the patronage of Cardinal Federico Borromeo.

49 Actorum Pars I, Concilia Provincialia V, 21579, AEM, USTC 842735.

$50 \quad A E M$, col. 557 .

$51 \quad A E M$, col. 557 .

$52 \quad A E M$, col. 557 .

53 Carlo Borromeo, Giovanni Testori (ed.), Memoriale ai Milanesi (Milan: Giordano Editore, 1965).

54 Testori, Memoriale, p. 50.
} 
contagion might return all the stronger, 'and not all the medicine and remedies will be enough to cure it' 55

Religious rhetoric has long drawn a connection between spiritual and physical illness, and Northern Italy saw many examples. A series of 1547 letters between the inquisition in Milan and officials in Cremona described the Lutheran sect as 'pullulating', a term that evoked the sprouting of plants, the swarming of insects, or the appearance of blisters on a body. They frequently referred to heresy as a type of 'plague' (peste), or to places and people as 'infected' (infetti) by heretical ideas. They pressed to need to both 'remedy' (ovviare) and 'uproot' (estirpare, estinguere) heresy. ${ }^{56}$ In a 1565 address to the first provincial council, Borromeo had used similarly medical language in his discussion of remedies: 'the method to be used in correcting delicts, following the nature of illnesses, is the one that adapts the medicine to the strength and quality of the sicknesses', yet also advocated 'a sharper cure, and finally applying iron and fire to the irritated parts, as the nature of the evil and the danger of contagion will demand ... ${ }^{57}$ Similarly, in his 1569 address, he made sense of the seeming return of the 'pestilential heresies' from the age of the 'ancient Fathers' as like an old illness returning to a body 'affect by some recent, even minor problem. ${ }^{58}$ The metaphor of illness provided Tridentine reformers with a model for explicating and treating heretical dissent.

The 'contagion' theory of heretical ideas may well help to explain the strong institutional focus on controlling means of communication and transit in Lombardy, shared by secular and religious authorities. Controls aimed at the spread of the plague also happened to include many known centers of Protestantism, such as Hungary, Croatia, Germany and the Grisons (1564), Geneva and Besançon (1567), Switzerland and its valleys (1568) and Basil and Lyon (1569). ${ }^{59}$ It is the nature of epidemiology that disease networks overlay those of trade and travel, and with its limited Alpine passes, there were reasonably set paths along which plague could travel to Milan. However, we might ask whether the system was primed to identify a physical threat with Northern influence, whether by xenophobia or design; as Ann Carmichael finds in a recent survey of the postmortems filed by the deputies of the magistracy of

\footnotetext{
$55 \quad$ Testori, Memoriale, p. 51 .

56 Assorted correspondence from inquisitors of Cremona. ASMi, Atti di governo, Culto, b.2104.

57 'Oration at the First Provincial Council ${ }_{15}$ October 1565' in Cihak (ed.), Selected Orations, pp. 29-30.

58 'Oration at the Second Provincial Council 24 April 1569' in Cihak (ed.), Selected Orations, pp. 29-30.

59 Various edicts in ASMi, Atti di Governo, Sanità, b.3.
} 
public health, 'they confirmed plague deaths, but (with practiced facility) they blamed plague's spread preemptively on travelers or undesirable migrants, or on infractions to good order by smugglers, tax evaders, and delinquent watchers' ${ }^{60}$ Based on the documents held at the Archivio di Stato in Milan, it appears that were fewer outright bans of communication and exchange with Genoa, Naples, and Vienna - hotspots for pestilence, but also Catholic centers under Habsburg control. While difficult to demonstrate a conscious program of limiting interaction with the Protestant North, there certainly appears to have been a socio-political calculus made as to the acceptability of such outright bans, disguised in the language of public health.

In his "Letter", Borromeo also emphasised the danger of such crossborder ties:

oh sons, in the opening that now allows commerce among the provinces and cities in the countryside ... where you have not been able to set foot in this time, that afflicted you with the water of the tribulation of the pestilence: what can you do but marvel at the thousands and thousands of men, who were submerged in this water among Milan, Venice, Mantua, Padua, Verona, Vicenza, Brescia and Pavia. ${ }^{61}$

Borromeo frequently invoked the metaphor of the biblical arc to underscore the exceptionality of Milan, but also the importance of its 'enclosure and exclusion' from its diluvial surroundings. ${ }^{62}$ Those regions are identified as the source of danger, with frequent reference to the 'many thousand dead in Mantua, Venice, and especially Brescia, a city so close to us, so small in proportion to ours.' ${ }^{63}$ In providing such claims to quantitative and qualitative knowledge about the plague, Borromeo evoked a similarly omnipotent quality to the edicts, while also stoking similarly xenophobic fears.

The Venetian representative in Milan, Ottavian di Marzi, offers an interesting view into how increasingly aggressive controls were justified in the name of public health, even to the point of diplomatic incidents with the duchy's neighbors to the east. Ottavian reported the news to the Venetian Council of

6o Ann G. Carmichael hypothesizes that there was a greater recognition of plague as 'something flowing from the countryside all around them, not something deliberately spread in the city by persons hoping to sustain the plague', encouraging the wider adoption of latent surveillance systems such as Milan's, see 'Plague Persistence in Western Europe: A Hypothesis', The Medieval Globe, 1 (2016), p. 167.

61 Testori, Memoriale, p. 28.

62 Testori, Memoriale, p. 28.

63 Testori, Memoriale, p. 31. 
Ten from his conversations with a 'friend' (often code for a paid informer) who had been deputised by the office of public health. 'Sovico' (likely the same Hieronymo Sovicus who appears in a February edict) lamented the danger posed by the 'Germans', who did not adequately inspect their churches and women. He feared that it was all part of a grander political scheme to occupy Savoy. Inspection for 'health' in this scenario was clearly linked with an inspection to detect the 'arms in great quantity of every sort' that the German merchants supposedly hid within their merchandise. The official claimed to know of this practice 'for sure' when the merchants were forced to come to him for a ticket 'without which they could not leave'.64 In this case, health inspections were clearly linked with surveillance intended to detect political and military threat.

For Marzi and his compatriots, November brought a stinging insult: the construction of cassotti within Venetian territories, a type of toll-station nominally intended to inspect such tickets and stem the tide of plague. Ottavian condemned the stations in the strongest terms (calling it a 'usurpation' made with 'the greatest temerity') as an infringement on Venice's jurisdiction, arguing that the authorities of Bergamo had already undertaken measures without this oversight. He confronted a relevant senator, then the head of Public Health directly, and even brought the matter before the Milanese senate. Over and over, he encountered the same rebuttal for every argument: that such an emergency situation demanded such emergency measures. The ministers even went as far as imprisoning the Venetian commissary sent to destroy the stations. ${ }^{65}$

The language of justification in the name of public health was omnipresent from 1576 forward. Marzi's account also references another important element of print plague policing: the 'tickets' (bolletini). This ephemeral bureaucratic documentation was as present in daily life as the edicts that enforced them. ${ }^{66}$ Tickets were pieces of paper that represented inspections and declared certain privileges related to trade and travel in a short standardised form. While existing in manuscript form for several centuries, the use of such tickets was made omnipresent during the plague years and continued well after. Even in the present day, travelers are often expected to provide evidence of good health, in addition to a political visa. Northern Italy and Switzerland became particularly notorious among travelers for their strict application of a ticketing

64 Letter by Ottavian di Marzi to Capi of the Council of Ten on 7 Aug 1575, Archivio di Stato di Venezia (ASVe), Capi del Consiglio diX, Dispacci degli ambasciatori, b. 16.

65 Letter by Ottavian di Marzi to the Senate on 8 Dec 1575 in ASVe, Senato, Dispacci degli ambasciatori, b. 4 .

66 Alexandra Bamji, 'Health Passes, Print and Public Health in Early Modern Europe', Social History of Medicine, 32:3 (2019), pp. 441-446. 
system, although it was hardly without its problems. See for example an early letter from Governor Gonzaga mentioning the difficulties faced by ticket officials in Como, aggravated by their own regular practice of extortion. ${ }^{67}$

A 1576 edict gave clear instructions for the use of the 'new' tickets. The responsibility was to be invested in individuals who were 'above all loyal and discrete' and able to carry out their duties punctiliously. Every individual who wished to travel would require such a printed ticket, while the new form was intended to clarify their use and invalidate older versions. The new ticket was to include 'age, distinctive marks, complexion, stature, name and surname, where they came from and where they went' as well as whether they traveled on horse or foot, the color of the horse, and the exact date of travel. Such tickets were not to be issued for any travel to or from infected areas. Three examples were provided at the bottom of the edict for individuals to presumably copy [Fig. 1.5] ${ }^{68}$ Comprehensive and individualised versions were likely often scrapped in favor of a more general print ticket on which the most pressing data (name, date, and place of travel) could be filled in as needed. ${ }^{69}$

Why did it matter that these forms were in print? They certainly derived from and continued to interact with the manuscript in ways that should qualify our eagerness to indicate a wholesale print revolution. However, the need or desire to utilise print for administration was shared by both secular and ecclesiastical authorities. The tickets speak to the scale of bureaucratic ambitions for social control, as well as to the authority and credibility that such a print item, though ephemeral, might carry. In fact, in the time of plague and years following, the Milanese seemed increasingly to turn to print for all kinds of answers. Samuel K. Cohn's analysis of Italian print publication for these years found that more than 378 publications related to the plague in the sixteenth-century, with more than $45 \%$ produced in the years of the plague itself $\left(1575^{-1578)} \cdot{ }^{70}\right.$ Nearly 115 texts were produced just within the years of 1576 and 1577. Importantly, these numbers do not include either broadsheets or the edicts analysed here. Even Cardinal Borromeo cited recent print literature, remarking in a letter of 1576 that the plague 'features in a book published

67 Copy of letter by Governor Gonzaga (27 Sept 1550) in ASVe, Senato, Dispacci degli ambasciatori, b. 4 .

68 'Instruttione per le nuove bollette et altro' (21 June 1576) in ASMi, Atti di governo, Sanità, b. 3 .

69 The use of the term 'stampare' in the edict to describe the tickets further support this, as do the printed licenses for inspectors. See example given to Lodovico Pallavicino (3o July 1577) in ASMi, Atti di governo, Sanità, b. 3.

70 Samuel K Cohn, Cultures of Plague: Medical Thinking at the End of the Renaissance (Oxford: Oxford University Press, 2012), p. 33. 
na come nella medefima grida fi contiene, alla quale inherendo, di nuouo fo licena pena commandano, che non ardilca alcuna perfona ne commiflario, ne deputato,nealuri, \& fia di che grado, digniti, \& titolo fi uoglia, fenza fpei licenza del detto Tribunale della Sanita in feritto, fotto alcun pretefto ne di

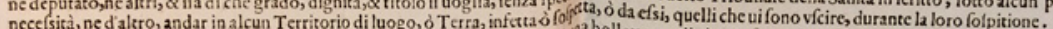

Che nó ardifca alcuna pfona di qual grado titolo, \& dignita fi fia, furrapire a cuna letta, ne di alcuna furrapita ufare, \& molto meno sforzare alcuna guardia, ò raftello, ne ctiá hauendo ragione, fotto pena per ciafcun capo, \& per do logiare ale di fcuti go.dioro, \& come fopra, oltra le altre pene già minacciate. Che niuno Hofte, ne che fia dentro dialcuna Terra, ne che fia fuora, ardicas ogiare alcuna periona, fia di che condition fi uogiia, fe non haueranno le fue lecgitime bollette, in tutto come fopra fi dice, Et fotto pena come lopd.

Che le Terre auuertifcano come paffa la cuftodia loro, perche ic qualch'uno ontrauerrà à gli ordini, fi dichiara che il Commune incorra nella pena, fenza difgrauamento petò del tranfgreffore, \& fe una Terra sinfetterà, fi faranto acofto del medefimo Commune, tutte le prouifioni non pur ordinarie, mà fraordinarie ancora, pur che efpedienti, faluo fempreliarbitrio di dettifignori.

Che i Commiffarij, oucro Deputati delle Terre, tengano conto di turti quxlishe ufciríno giomo per giorno delle Terre loro, \& ne ficciano raffegna la fera.

Che oltra alla particular cura che doucrino hauere i Commiflarij ouero Defelati delle Terre infette, che niuno efca de i loro Territorij, fecondo la grida di Cheoltra afla particular cura che dotcrino haterei Commiliarijouciol

7. ftante, habbiano anco le Terte circonuicine da farui la guardia
Per meglio accertare l'offeruanza della prefente grida ficommanda àte leperfone, che haucranno notitia di qualche tranfgrefsione, che debbano darne notitia all'Officio de i fuderti Signori, i quali per quetto effetto, di tuttelicidette pene pecuniarie applicate al detto loro oflicio, ne promettono liberamente \& applicano la terza parte a gli accufatori, i quali in olere farancotenuti fecreti.

Auuertendo tutti, che fi procederà cootra i tranfgrefori rigorofamente \& irtemifsibilmente.

Ancora che il Tribunale haueffe conceffa a chi fi uoglia patente olicenza diablite in alcun luogo, Nondimeno perehe fempre in effe fi pone che fi habbiano dhauere le leggitime bollette, i Deputati, al far effe bollette, confiderernno diligentemente, fe quel tale che tiene la detta patente ò licenza è libero da ogni fofpitione contagiofa, \& trouando di fi,gli facciano la bolletta come fopra, trouando di nó; non gli facciano in alcun modo alcuna bolletta.

G. Brugora Prafes.

H. Montius.

Gio. Filippo Gherardini, perlo Nag. Canallier Sowico.

Forma di bolletre a gli habitanti delle feffe Terre. | Forma di bolletsa, pe gi habitanti delle Caffine.

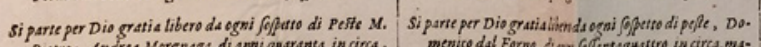

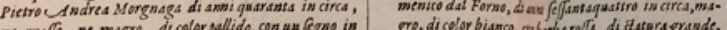

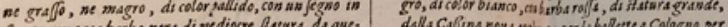

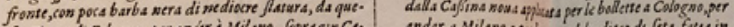
fa Terra di Cologno, per aniar d Milano, fopra vn Ca. wallo baio fouro, fenza valgia, ne altro.

Deft in Cologno adi irg. Cagno 1577. Gio. Antenio Inzagroepatato di Cologno. andar a Milano a pisk, cess Lib. dicce di forta fatha in efta Cojinas.

Dats in Cologno adi ry. Giugue 1577 .

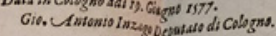
Per pastzgio. Viffa in Cologmo, ơ cेbrons Adu Giagno, t577

a bere so.

Gio. Unienio Inzago Deparato di Cologno.

Perritorns.

iunfe quì adi i7. del prefence a bere ry. of hors torms d

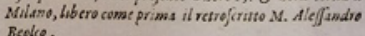
Besico.

Data in Cologno adi rg. Giugno, 1577 , à bore $2 t$.

Gio. Antonio Inzago Deputato di Cologno.

In Milano, per Gio.Bsttifta Pontio,ftampąiore dell'Offitio della Sanità del Stato di Milano.

FIGURE 1.5 Edict of 21 June 1576 in ASMi, Atti di governo, Sanità, busta 3

REPRODUCED WITH PERMISSION OF THE ARCHIVIO DI STATO DI MILANO

here', which indicated the salutary properties of religious processions. ${ }^{71}$ It is difficult to recreate the popular sentiment of the Milanese in this period, particularly due to the lacunae in the archival record. Given the chaos caused by such a high mortality rate, we might reasonably imagine there was something comforting about all of these printed words, and even the draconian measures they sometimes imposed. The printed edict and ticket could convey an active, informed, and pre-emptively prepared governing authority in uncertain times.

The development of such tickets might seem to slot neatly into the history of the secular state, but we see an exact mirroring in the ecclesiastical context

71 This could be a book referenced by Borromeo in his Memoriale: Salvianus, De gubernatione Dei (Paris: Sébastien Nivelle, 1580), USTC 172421. Letter by Carlo Borromeo to Niccolò Ormaneto (6 September 1576) in Carlo Borromeo, Marina Bonomelli (ed.), Milano e la corte di Spagna: un carteggio inedito di Carlo Borromeo (Milan/ Rome: Biblioteca Ambrosiana, 2008), pp. 167-171. 
by Cardinal Borromeo. He intended to institute a system of confession tickets in "Advice for those who maintain the records of the state."72 These slips of paper would be filled out at the time of the confession, held by the devotee, and handed to the priest before receiving communion. Overall, the tickets would be part of a four-part administrative documentation, along with the parish register (status animarum), approved list of confessors, and list of the unconfessed. Borromeo even attempted to mandate that the ill confess promptly and show the ticket, 'otherwise doctors are not to treat them, under penalty of excommunication.' ${ }^{73}$ The 1574 synod visitation memo indicated that the tickets were nonetheless widely disregarded. In Gorgonzola, the clergy protested that they 'knew all their devotees', but the inspectors commented that they seemed to admit all without distinction. Under the inspector's description of Capriasca, the excuses are simply abbreviated as 'they do not use the tickets because they trust, etc. ${ }^{74}$ However, Borromeo did not alter his demands, offering a model in the "Advice" of just such a ticket that might be pre-printed and filled out as necessary, similar to those provided for the plague tickets some years before. ${ }^{75}$ He further reminded the clergy of Milan that all foreigners only be admitted to the Metropolitan church, and that they needed to be recorded in a book with their name, last name, place of origin, or domicile from which they came, and their itineraries. 'Keep this book faithfully', he chastised, 'and every fifteen days write to us, signed and affirmed in your hand. ${ }^{76}$

Borromeo sought to carve space for the Inquisition in commercial and diplomatic relations, cultivating a culture of self-reporting. In keeping with the contagion model of heretical dissent, Borromeo was concerned that Milanese merchants might become infected by aberrant practices while abroad in the nearby Protestant North. In 1580, Borromeo printed instructions for just such merchants, requiring that they receive a ticket from a religious authority

72 'Avvertenze a ciascun curato per far i libri del stato delle su anime' (1574) in Pars Iv Reliqua ad instructionem aliquam pertinentia vulgari sermone conscripta, AEM, col. 1934-1988. See also De Boer, The Conquest of the Soul, pp. 187-192.

73 'Avvertimenti per il sacramento della cresima' (1582), in Pars IV Reliqua, AEM, col. $1773^{-1775 . ~}$

74 '1574, Memoriali dei Vicari Forenei per il Sinodo Diocesano' in Angelo Turchini (ed.), 'Appendice', Monumenta borromaica, (Cesena: Il ponte vecchio, 2010), pp. 147-171. Original cited from Archivio Diocesano Milano, Memoriali diversi, Sez. VI.

75 'Avvertenze a ciascun ... libri del stato', in Pars Iv Reliqua, AEM, col. 1934-1935.

76 'Avvertenze di Mons. Illustr. Card. Di S. Prassede Arcivescovo di Milano ai Curati della Citta e Diocesi Sua ...' in Pars IV: Instructiones variæ - Reliqua ad instructionem aliquam pertinentia vulgari sermone conscripta, $A E M$, col. $1775^{-1776}$. Previously published under same title (Milan: Valerio et Hieronimo fratelli da Meda, 1574), ustc 842542, \& (Milan: Pacifico da Ponte, 1574), ustc 84254. 
certifying a character investigation to establish the purity of their faith. Like the secular edicts, the order included the instructions for its own promulgation, so that 'no man might plead ignorance. ${ }^{77}$ In combination with the participation records that Borromeo encouraged all priests to keep, the tickets would have supported a system of religious 'passports'. The resulting paperwork would constitute a systematic database of potential heresy cases. The character investigation, while potentially weeding out those with a weak religious 'constitution', would also propagandise the dangers of travel, perhaps dissuading a would-be traveler.

It would not be out of the scope of possibility for Borromeo to double-down on a failed strategy, but as with the secular edicts and use of tickets, it seems that the systematic integration of this bureaucratic documentation had made some headway over the course of the 1570s. While authorities in Milan struggled to control the public sphere (and still contested it with one another) they now focused on weaving a web of social control through print. Edicts and acts presented the outward face of bureaucracy, as well as generating internal coherence. Lombard residents were expected to keep apprised of new regulation and take part in a constant program of information collection, from the deputies that performed postmortems, to approved priests hearing confessions, to anonymous informers rewarded for their denunciations.

\section{Conclusion: A Lasting Legacy}

In 1578, Borromeo wrote to Phillip II to protest the lodging and conduct of a contingent of German soldiers nearby, who 'lived heretically', 'publically showed various injuries and irreverences' towards the Catholic ritual, and were 'eating meat every day indifferently' ${ }^{\prime}$ 'I leave it to Your Majesty to consider what poor conduct (scandalo) they transmit to these people, what a danger they might be, how they corrupt and contaminate (corrompere e contaminar) with this plague the simple and rough people of these places', he declared, arguing that they not be allowed to 'infect (infettar) others with their pernicious example.79 Yet Borromeo did not receive the response he wished, forced instead in later letters to defend his latest antagonisms of the governor and

77 'Letera a Parochi per quelli che vanno a terre d'Heretici' (1580), Edicta varia, ordinationes et decreta, AEM, col. 1105-1106.

78 Letters from Cardinal Borromeo to Phillip II of Spain (1578), in Bonomelli, Milano e la corte di Spagna, pp. 196-197, 200-201.

Bonomelli, Milano e la corte di Spagna, pp. 196-197, 200-201. 
senate. The culmination of these petty conflicts in the 1580 print shop raid reminds us that while Cardinal Borromeo and the Marquis d'Ayamonte may have developed similar rhetorical and print strategies as a result of the plague years, they were rarely deliberate allies in the fight for social control. ${ }^{80}$

Both the cardinal and governor recognised the public print voice as an invaluable resource, and sought to quell their competition. The plague years had shown how the press could enable the expansion of a secular or ecclesiastical bureaucracy, and then effectively propagandize that same achievement. The 158os production and export of the Edicts and Acts compilations monumentalised them for international readers. Yet it was the new daily presence of authority in print governing trade, travel and even devotion in Lombardy that was the most lasting legacy. Both Borromean church and Spanish state benefitted from this advance in early informatics.

The proscriptive nature of these documents provides evidence for two things: on the one hand, they can be interpreted as expressing the interests and authority of the governing powers. On the other hand, they indicate the need for continual crackdown. The acceptance of social controls in daily life did not equate with a total obedience. Throughout the next decades, edicts prohibiting gambling over the election of clergy and posting nighttime pasquinades (pasquini) indicate continuing sacrilegiousness. ${ }^{81}$ However, the political and religious docility of Milan over the next century was truly a historical anomaly: of all the Spanish possession, this former nest of would-be traitors and heretics was the only one to not revolt against its foreign rulers. The expanded role of the church and state in governing daily life appears to have been largely accepted, and certainly current scholarship speaks of Milan as a hub of the Counter- and Catholic Reformation.

The transformation also worked in two ways: these new information systems embedded the public in governance, but they also drew authorities into a constant interaction and monitoring of the public sphere. In 1584, Borromeo spoke to an audience of priests, chastising them by saying that Swiss visitors, on returning home, proclaimed "the priests in Milan, who are examples for everyone else, do such and such, live in such and such a way, speak in such

8o This difference was also reflected by two rival theories as to the initial source of the plague. Bugato and Bestia believed it may have been spread by religious pilgrimage, while an anonymous doctor writing in 1577 placed the blame with Spanish soldiers arriving from Sicily. Cosmacini, Il medico, pp. 69-70.

81 'Sopra i Pasquini' (12 Apr 1583) \& 'Grida, che non si possa far scomesse per l'elettione de' Sommi Pontefici, \& Cardinali' (3o Aug 1591) in Pandolfo Malatesta (ed.), Compendio di tutte le gride e ordini publicati nella Città e Stato di Milano (Milan: Malatesti, [1609]), USTC 4039281 . 
and such a way; and so they are allowed to be much worse than us. ${ }^{82}$ Many of the Milan edicts from the 158 os played into Protestant stereotypes of Spanish authoritarianism, a particularly striking example being an edict banning rowdiness at comedies..$^{83}$ The decades before the Thirty Years' War were a high point for censorship as governments chased the specter of controlling public opinion and expression. ${ }^{84}$ Borromeo's own 1582 "Orders to be Observed by Booksellers, Printers, and Others" sought to establish Inquisitorial censorship as the standard, rather than the exception, for all vernacular books, which were to be submitted to the Inquisitor and diocese for written approval 'for the common benefit'. ${ }^{85}$ Possession of any vernacular bible or text treating 'controversies with heretics' was only allowed to only 'mature' readers who would not fall into error. Books published in Venice; used books; and books authored 'by diverse authors', common pseudonyms such as 'Simon Simonio', or known authors such as Flaminio and Erasmus, were banned entirely. ${ }^{86}$

The control of foreign influence can be viewed as a final ramification of the plague years and its systems of social control. The 158 os saw a flood of edicts that elaborated the ticketing systems of earlier years, with particularly strict ramifications threatened for innkeepers who failed in mandatory reporting. ${ }^{87}$ In his travels of Lombardy in the first decade of the seventeenthcentury, the Scottish Protestant Fynes Moryson was positively paranoid about Spanish Catholic surveillance. He opted to forego travel by post and coach entirely to avoid drawing attention. In a comic moment, Moryson even encountered another Englishman at his public inn in disguise as a Frenchman. Failing to communicate properly in French or German, the man 'tooke me for a spie, and feared I should betray him, and presently went into the stable, where he commanded his servant to saddle their horses, that they might ride all night towards Genoa. But I following him, and boldly speaking English to him, he was soone content to stay all night, and to take me in my homely apparell for

82 'Homily to the canons of the major church and collegiate churches of Milan given in the Archbishop's House Chapel January 2, 1584' in Cihak (ed.), Selected Orations, p. 129.

83 'Che non si faccia questione, ne risse alle Comedie' (3 Aug 1585) in Malatesta, Compendio.

84 Geoffrey Parker, The Grand Strategy of Philip II (New Haven: Yale University Press, 200o); Paolo Preto, I servizi segreti di Venezia (Milan: Il Saggiatore, 1994).

85 Ordini da osservarsi da librari, stampatori, ed altri (1582) in Edicta varia, ordinationes et decreta, AEM, col. 1107-1111.

86 Ordini da osservarsi da librari, stampatori, ed altri (1582) in Edicta varia, ordinationes et decreta, AEM, col. 1107-1111.

87 'Sopra l'allogiar i Forastieri' (16 July 1585); 'Grida, che prohibisce a forestieri l'entrare in questo Stato' (11 Sept 159o); 'Grida contra banditi forastieri, che dimorano in questo stato' (13 Feb 1592) in Malatesta, Compendio. 
his bedfellow' ${ }^{88}$ The fear of surveillance that foreign Protestants felt in Milan stands in stark contrast to their relative comfort in the mid-sixteenth century.

The contagion theory of plague and accompanying program of governance and ecclesiastical ministry had long-term effects for the development of the Duchy of Milan. The climate prior to Borromeo's arrival and into the first decade of his work was largely hostile. Lombard residents were more likely to reject authoritarian intervention, expressing discontent through delegations to the Spanish court, attacks on the Inquisition, and conspiracies with Protestant or French allies. The series of pestilences in the 1560 , followed by the advent of the plague of $1576-1578$, created a new emergency. Spanish authorities and local governance established a program utilising print edicts and tickets for social control. At the same time, Borromeo's Acts emphasised the connection between spiritual and physical health and illness, and adopted many of the same methods for controlling the 'contagion' of heresy and dissent. The ephemeral tickets, which largely do not survive, and the memorialised acts and edicts, which do, demonstrate the influence of this shared environment on bureaucratic development of both religious and secular governance.

88 Fynes Moryson, An Itinerary Written by Fynes Moryson (London: John Beale 1617), ESTC Cit. S115249, pp. 168-169. USTC 3007471. 